\title{
Composition of vaginal microbiota and their antibiotic susceptibility in symptomatic women
}

\author{
Ushadevi Gopalan ${ }^{1 *}$, Sathiyakala Rajendiran', Karthika Jayakumar², \\ Ranganathan Karnaboopathy ${ }^{3}$
}

\begin{abstract}
${ }^{1}$ Department of Obstetrics and Gynecology, ${ }^{2}$ Department of Microbiology, ${ }^{3}$ Department of Community Medicine, Shri Sathya Sai Medical College and Research Institute, Ammapettai, Kancheepuram, Tamil Nadu, India
\end{abstract}

Received: 30 December 2016

Revised: 06 January 2017

Accepted: 18 January 2017

\section{*Correspondence: \\ Dr. Ushadevi Gopalan, \\ E-mail: ushag7@hotmail.com}

Copyright: (c) the author(s), publisher and licensee Medip Academy. This is an open-access article distributed under the terms of the Creative Commons Attribution Non-Commercial License, which permits unrestricted non-commercial use, distribution, and reproduction in any medium, provided the original work is properly cited.

\begin{abstract}
Background: Bacterial vaginosis is the most prevalent lower genital tract infection in women of reproductive age. The aim of this study was to identify the causative organism in patients with vaginal discharge and to study the sensitivity of the organism to antibiotics.

Methods: This was a hospital based prospective study in Department of Obstetrics and Gynecology in a tertiary care hospital over a period of two years. 2062 women with complaints of vaginal discharge were subjected to a high vaginal swab and the sample was cultured, the organisms were identified and antibiotic susceptibility was tested.

Results: There was no growth found in $40.7 \%$ of patients. E. coli was found to be the most common organism isolated followed by Klebsiella pneumonia and Klebsiella oxytoca. Candida species was isolated in $1.4 \%$ of women. An increased frequency of vaginal infection was found in the age group 26-35 years, followed by age group 36-45 years. $73.2 \%$ of the organisms were sensitive to Imipenam, $70.4 \%$ to Amikacin and $65.7 \%$ to Gentamycin. There were 10 MRSA strains isolated all of which were sensitive to Vancomycin, Amikacin and Gentamycin.

Conclusions: Our study provides information about the different microorganisms present in women with vaginal discharge. Since pathogenic bacteria were more common than Candida species it is recommended to offer treatment to patients after taking a high vaginal swab. Appropriate antibiotics based on culture and sensitivity has to be given along with antifungal agents.
\end{abstract}

Keywords: Bacterial vaginosis, Culture and sensitivity, High vaginal swab, Vaginal discharge

\section{INTRODUCTION}

Vagina is a complex ecosystem consisting of a variety of microorganism. ${ }^{1}$ Females are more prone to urinary and vaginal infections because of the anatomical and functional proximity to anal canal and due to the short urethra. $^{2}$ Bacterial vaginosis is the most prevalent lower genital tract infection in women of reproductive age throughout the world. ${ }^{3}$ It affects millions of women annually and is strongly associated with several adverse health outcomes including preterm labor and delivery, pelvic inflammatory disease, postpartum and postabortal endometriosis. ${ }^{4-7}$ It is the most common cause of vaginal symptoms prompting women to seek medical care. ${ }^{8}$

The human body harbors hundreds of organisms of gram positive and gram negative varieties in the lower one third of the vagina. ${ }^{9}$ Infection or inflammation of the vagina is called vaginitis. The two most common causes of vaginitis are bacterial vaginitis and Candida vaginitis. ${ }^{10}$ The causative organisms may be sexually transmitted, endogenous or iatrogenic. Abnormal vaginal discharge may be the only symptom of bacterial vaginitis 
and many affected women are asymptomatic. ${ }^{11}$ Zhou et al have suggested that a certain number of women who do not have any symptoms have vaginal communities that resemble bacterial vaginosis. ${ }^{12}$

As vaginitis causes lots of discomfort to the woman and her quality of life is affected we should diagnose and treat the condition correctly. Treating women with vaginal discharge empirically with antifungal therapy assuming that the causative organism is Candida without taking a high vaginal swab culture and sensitivity is still in practice. $^{10}$ Another existing treatment for bacterial vaginosis-oral or vaginal administration of metronidazole is plagued by high failure rates with recurrence of symptoms in $54 \%$ of women within three months of antibiotic treatment. ${ }^{13}$

The aim of this study was to identify the causative organism in patients with vaginal discharge and to study the sensitivity of the organism to antibiotics. By studying the sensitivity of these strains of organism we may be able to decide on a suitable treatment protocol for these women and alleviate the misery of these women with vaginal discharge.

\section{METHODS}

This was a hospital based prospective study conducted in the Department of Obstetrics and Gynecology in a tertiary care teaching hospital over a period of two years from October 2014 to September 2016. 2062 women aged between 18 and 60 years who had presented to the gynecology OPD with complaints of vaginal discharge were included in the study. Informed consent was taken from the patient. During the visit the patient was put into lithotomy position and a sterile Cusco's speculum was introduced into the vagina and a high vaginal swab was taken using aseptic precautions. The swabs were transported to the microbiology laboratory immediately and processed.

The sample was cultured using Mac Conkey agar for gram negative bacteria and blood agar and chocolate agar for gram positive bacteria at $37^{\circ} \mathrm{C}$ and incubated for 48 hrs. Conventional methods and biochemical tests were performed and the organism was identified as per NCCLS guidelines. ${ }^{14}$ Antibiotic susceptibility was tested using disc diffusion methods by incubating at $37^{\circ} \mathrm{C}$ for 24 hrs. All women found positive for culture and sensitivity were treated with appropriate antibiotics. Data obtained was analyzed for distribution of microorganism with respect to age, number and percentage of women from whom the particular microorganism was isolated and the antibiotic sensitivity. Analysis was done using Microsoft Excel Program. Based on the data analysis results were obtained regarding the age specific organism, infectivity pattern and antibiotic sensitivity pattern.

\section{RESULTS}

The data from the high vaginal swab culture and sensitivity results of the 2062 women were analyzed by percentage analysis using SPSS software. Of the 2062 women around $1222(59.3 \%)$ had positive vaginal cultures. Total of 23 microorganisms were isolated.

Table 1 shows the frequency and percentage of symptomatic women in the different age groups in the study. There were 307 women (14.9\%) in the age group $18-25$ yrs, 793 women $(38.5 \%)$ in the age group 26-35 yrs, 624 women $(30.3 \%)$ in the age group 36-45 and 338 women $(16.4 \%)$ aged above 45 years.

Table 1: Age distribution of the patients.

\begin{tabular}{|lll|}
\hline Age group (Years) & Frequency & Percent (\%) \\
\hline $18-25$ & 307 & 14.9 \\
\hline $26-35$ & 793 & 38.5 \\
\hline $36-45$ & 624 & 30.3 \\
\hline Above 45 & 338 & 16.4 \\
\hline Total & $\mathbf{2 0 6 2}$ & $\mathbf{1 0 0 . 0}$ \\
\hline
\end{tabular}

Table 2: Distribution of microorganism with respect to age.

\begin{tabular}{|lllllll|}
\hline Age group & No growth & K. pneumoniae & K. oxytoca & Acinetobacter & Chlanydia & E. coli \\
\hline $18-25$ & $115(5.6 \%)$ & $33(1.6 \%)$ & $28(1.4 \%)$ & $12(0.6 \%)$ & $1(0.05 \%)$ & $54(2.6 \%)$ \\
\hline $26-35$ & $344(16.7 \%)$ & $74(3.6 \%)$ & $52(2.5 \%)$ & $33(1.6 \%)$ & $6(0.3 \%)$ & $117(5.7 \%)$ \\
\hline $36-45$ & $255(12.4 \%)$ & $56(2.7 \%)$ & $50(2.4 \%)$ & $33(1.6 \%)$ & $4(0.2 \%)$ & $108(5.2 \%)$ \\
\hline Above 45 & $126(6.1 \%)$ & $22(1.1 \%)$ & $20(1 \%)$ & $12(0.6 \%)$ & $1(0.05 \%)$ & $96(4.7 \%)$ \\
\hline Total & $\mathbf{8 4 0}(\mathbf{4 0 . 7} \%)$ & $\mathbf{1 8 5}(\mathbf{9} \%)$ & $\mathbf{1 5 0}(\mathbf{7 . 3 \%})$ & $\mathbf{9 0}(\mathbf{4 . 4 \%})$ & $\mathbf{1 2}(\mathbf{0 . 6 \%})$ & $\mathbf{3 7 5}(\mathbf{1 8 . 2 \%})$ \\
\hline
\end{tabular}

Table 3: Distribution of microorganism with respect to age.

\begin{tabular}{|llllll|}
\hline Age group & $\begin{array}{l}\text { Pseudomonas } \\
\text { aeruginosa }\end{array}$ & Staphylococcus & Citrobacter & $\begin{array}{l}\text { Enterococcus } \\
\text { fecalis }\end{array}$ & $\begin{array}{l}\text { Streptococcus } \\
\text { pyogenes }\end{array}$ \\
\hline $18-25$ & $12(0.6 \%)$ & $21(1 \%)$ & $8(0.4 \%)$ & $4(0.2 \%)$ & $6(0.3 \%)$ \\
\hline $26-35$ & $46(2.2 \%)$ & $48(2.3 \%)$ & $15(0.7 \%)$ & $19(0.9 \%)$ & $11(0.5 \%)$ \\
\hline $36-45$ & $24(1.2 \%)$ & $38(1.8 \%)$ & $11(0.5 \%)$ & $10(0.5 \%)$ & $15(0.7 \%)$ \\
\hline Above 45 & $15(0.7 \%)$ & $16(0.8 \%)$ & $4(0.2 \%)$ & $9(0.4 \%)$ & $6(0.3 \%)$ \\
\hline Total & $\mathbf{9 7}(\mathbf{4 . 7 \%})$ & $\mathbf{1 2 3}(\mathbf{6 \%})$ & $\mathbf{3 8}(\mathbf{1 . 8 \%})$ & $\mathbf{4 2}(\mathbf{2 \%})$ & $\mathbf{3 8 ( 1 . 8 \% )}$ \\
\hline
\end{tabular}


Table 4: Distribution of microorganism with respect to age.

\begin{tabular}{|lll|llll|}
\hline Age group & $\begin{array}{l}\text { Proteus } \\
\text { vulgaris }\end{array}$ & $\begin{array}{l}\text { Streptococcus } \\
\text { pneumonia }\end{array}$ & MRSA & $\begin{array}{l}\text { Coagulase negative } \\
\text { staphylococcus }\end{array}$ & $\begin{array}{l}\text { Proteus } \\
\text { mirabilis }\end{array}$ & $\begin{array}{l}\text { Enterobacter } \\
\text { aerogenes }\end{array}$ \\
\hline $18-25$ & 0 & $2(0.1 \%)$ & $3(0.1 \%)$ & 0 & 0 & 0 \\
\hline $26-35$ & $4(0.2 \%)$ & $2(0.1 \%)$ & $3(0.1 \%)$ & 0 & $1(0.05 \%)$ & $2(0.1 \%)$ \\
\hline $36-45$ & $1(0.05 \%)$ & 0 & $3(0.1 \%)$ & $2(0.1 \%)$ & $5(0.2 \%)$ & $1(0.05 \%)$ \\
\hline Above 45 & $4(0.2 \%)$ & 0 & $1(0.05 \%)$ & 0 & $3(0.1 \%)$ & $2(0.1 \%)$ \\
\hline Total & $\mathbf{9 ( 0 . 4 \% )}$ & $\mathbf{4 ( 0 . 2 \% )}$ & $\mathbf{1 0}(\mathbf{0 . 5 \%})$ & $\mathbf{2 ( 0 . 1 \% )}$ & $\mathbf{9 ( 0 . 4 \% )}$ & $\mathbf{5 ( 0 . 2 \% )}$ \\
\hline
\end{tabular}

Table 5: Distribution of microorganism with respect to age.

\begin{tabular}{|lllllll|}
\hline Age group & C. & C. Koserindii & $\begin{array}{l}\text { Pseudomonas } \\
\text { putida }\end{array}$ & $\begin{array}{l}\text { Staphylococcus } \\
\text { saprophyticus }\end{array}$ & $\begin{array}{l}\text { Morganella } \\
\text { morganii }\end{array}$ & Candida \\
\hline $18-25$ & 0 & 0 & $1(0.05 \%)$ & $1(0.05 \%)$ & 0 & $6(0.3 \%)$ \\
\hline $26-35$ & $1(0.05 \%)$ & $1(0.05 \%)$ & 0 & 0 & $1(0.05 \%)$ & $13(0.6 \%)$ \\
\hline $36-45$ & 0 & 0 & 0 & 0 & 0 & $8(0.4 \%)$ \\
\hline Above 45 & 0 & 0 & 0 & 0 & 0 & $1(0.05 \%)$ \\
\hline Total & $\mathbf{1 ( 0 . 0 5 \% )}$ & $\mathbf{1 ( 0 . 0 5 \% )}$ & $\mathbf{1 ( 0 . 0 5 \% )}$ & $\mathbf{1 ( 0 . 0 5 \% )}$ & $\mathbf{1 ( 0 . 0 5 \% )}$ & $\mathbf{2 8}(\mathbf{1 . 4 \% )}$ \\
\hline
\end{tabular}

Table 2 to 5 shows the distribution of the different organism with respect to age. There was no growth found in $40.7 \%$ of patients. The microorganism with the highest frequency of infection was $E$. coli which was found in 375 women $(18.2 \%)$ followed by Klebsiella pneumoniae in 185 women (9\%) followed by Klebsiella oxytoca in 150 women $(7.3 \%)$. In the next order of frequency was found Staphylococcus in 123 women (6\%) followed by Pseudomonas aeruginosa in 97 women (4.7\%), Acinetobacter in 90 women (4.4\%) followed by Enterococcus fecalis in 42 women (2\%). Candida species was isolated in only 28 women $-1.4 \%$ of study patients with the highest prevalence in the age group 26-35 years.
Other organisms such as Citrobacter, Streptococcus pyogenes, Streptococcus pneumoniae, Proteus vulgaris, Proteus mirabilis, Coagulase negative staphylococcus, Enterobacter aerogenes, Citro freundii, Citro koseri, Pseudomonas putida, Staphylococcus saprophyticus and Morganella morganii were also isolated. Chlamydia species was isolated in 12 women $(0.6 \%)$ and MRSA isolated in 10 women $(0.5 \%)$.

Table 6 to 9 shows the frequency of the microorganisms in the different age groups. An increased frequency of infection was found in the age group 26-35 years followed by the age group 36-45 years.

Table 6: Frequency of microorganisms in the different age groups.

\begin{tabular}{|lllllll|}
\hline Age group & No growth & K. pneumoniae & K. oxytoca & Acinetobacter & Chlamydia & E. coli \\
\hline $18-25$ & $115(13.69 \%)$ & $33(17.84 \%)$ & $28(18.67 \%)$ & $12(13.33 \%)$ & $1(8.33 \%)$ & $54(14.4 \%)$ \\
\hline $26-35$ & $344(40.95 \%)$ & $74(40 \%)$ & $52(34.67 \%)$ & $33(36.67 \%)$ & $6(50 \%)$ & $117(31.2 \%)$ \\
\hline $36-45$ & $255(30.36 \%)$ & $56(30.27 \%)$ & $50(33.33 \%)$ & $33(36.67 \%)$ & $4(33.33 \%)$ & $108(28.8 \%)$ \\
\hline Above 45 & $126(15 \%)$ & $22(11.89 \%)$ & $20(13.33 \%)$ & $12(13.33 \%)$ & $1(8.33 \%)$ & $96(25.6 \%)$ \\
\hline Total & $\mathbf{8 4 0}(\mathbf{1 0 0} \%)$ & $\mathbf{1 8 5}(\mathbf{1 0 0 \%})$ & $\mathbf{1 5 0}(\mathbf{1 0 0 \%})$ & $\mathbf{9 0}(\mathbf{1 0 0} \%)$ & $\mathbf{1 2}(\mathbf{1 0 0} \%)$ & $\mathbf{3 7 5}(\mathbf{1 0 0 \%})$ \\
\hline
\end{tabular}

Table 7: Frequency of microorganisms in the different age groups.

\begin{tabular}{|llllll|}
\hline Age group & $\begin{array}{l}\text { Pseudomonas } \\
\text { aeruginosa }\end{array}$ & $\begin{array}{l}\text { Staphylococcus } \\
\text { Citrobacter }\end{array}$ & $\begin{array}{l}\text { Enterococcus } \\
\text { fecalis }\end{array}$ & $\begin{array}{l}\text { Streptococcus } \\
\text { pyogenes }\end{array}$ \\
\hline $18-25$ & $12(12.37 \%)$ & $21(17.07 \%)$ & $8(21.05 \%)$ & $4(9.52 \%)$ & $6(15.79 \%)$ \\
\hline $26-35$ & $46(47.42 \%)$ & $48(39.02 \%)$ & $15(39.47 \%)$ & $19(45.24 \%)$ & $11(28.95 \%)$ \\
\hline $36-45$ & $24(24.74 \%)$ & $38(30.89 \%)$ & $11(28.95 \%)$ & $10(23.81 \%)$ & $15(39.47 \%)$ \\
\hline Above 45 & $15(15.46 \%)$ & $16(13.01 \%)$ & $4(10.53 \%)$ & $9(21.43 \%)$ & $6(15.79 \%)$ \\
\hline Total & $\mathbf{9 7 ( 1 0 0 \% )}$ & $\mathbf{1 2 3}(\mathbf{1 0 0 \%})$ & $\mathbf{3 8}(\mathbf{1 0 0 \%})$ & $\mathbf{4 2}(\mathbf{1 0 0 \%})$ & $\mathbf{3 8 ( 1 0 0 \% )}$ \\
\hline
\end{tabular}


Table 8: Frequency of microorganisms in the different age groups.

\begin{tabular}{|lllllll|}
\hline $\begin{array}{l}\text { Age } \\
\text { group }\end{array}$ & $\begin{array}{l}\text { Proteus } \\
\text { vulgaris }\end{array}$ & $\begin{array}{l}\text { Streptococcus } \\
\text { preumonia }\end{array}$ & MRSA & $\begin{array}{l}\text { Coagulase negative } \\
\text { staphylococcus }\end{array}$ & $\begin{array}{l}\text { Proteus } \\
\text { mirabilis }\end{array}$ & $\begin{array}{l}\text { Enterobacter } \\
\text { aerogenes }\end{array}$ \\
\hline $18-25$ & 0 & $2(50 \%)$ & $3(30 \%)$ & 0 & 0 & 0 \\
\hline $26-35$ & $4(44.4 \%)$ & $2(50 \%)$ & $3(30 \%)$ & 0 & $1(11.11 \%)$ & $2(40 \%)$ \\
\hline $36-45$ & $1(11.2 \%)$ & 0 & $3(30 \%)$ & $2(100 \%)$ & $5(55.56 \%)$ & $1(20 \%)$ \\
\hline Above 45 & $4(44.4 \%)$ & 0 & $1(10 \%)$ & 0 & $3(33.33 \%)$ & $2(40 \%)$ \\
\hline Total & $\mathbf{9 ( 1 0 0 \% )}$ & $\mathbf{4 ( 1 0 0 \% )}$ & $\mathbf{1 0}(\mathbf{1 0 0 \% )})$ & $\mathbf{2 ( 1 0 0 \% )}$ & $\mathbf{9 ( 1 0 0 \% )}$ & $\mathbf{5 ( 1 0 0 \% )}$ \\
\hline
\end{tabular}

Table 9: Frequency of microorganisms in the different age groups.

\begin{tabular}{|lllllll|}
\hline Age group & C. Freundii & C. Koseri & $\begin{array}{l}\text { Pseudomonas } \\
\text { putida }\end{array}$ & $\begin{array}{l}\text { Staphylococcus } \\
\text { saprophyticus }\end{array}$ & $\begin{array}{l}\text { Morganella } \\
\text { morganii }\end{array}$ & Candida \\
\hline $18-25$ & 0 & 0 & $1(100 \%)$ & $1(100 \%)$ & 0 & $6(21.4 \%)$ \\
\hline $26-35$ & $1(100 \%)$ & $1(100 \%)$ & 0 & 0 & $1(100 \%)$ & $13(46.43 \%)$ \\
\hline $36-45$ & 0 & 0 & 0 & 0 & 0 & $8(28.57 \%)$ \\
\hline Above 45 & 0 & 0 & 0 & 0 & 0 & $1(3.57 \%)$ \\
\hline Total & $\mathbf{1 ( 1 0 0 \% )}$ & $\mathbf{1 ( 1 0 0 \% )}$ & $\mathbf{1 ( 1 0 0 \% )}$ & $\mathbf{1 ( 1 0 0 \% )}$ & $\mathbf{1 ( 1 0 0 \% )}$ & $\mathbf{2 8}(\mathbf{1 0 0 \% )}$ \\
\hline
\end{tabular}

Table 10 shows the sensitivity and resistance patterns of the microorganisms to the common antibiotics used. 73.2 $\%$ of the microorganisms were sensitive to Imipenam, $70.4 \%$ were sensitive to Amikacin, $65.7 \%$ sensitive to Gentamycin and $47.2 \%$ sensitive to Ciprofloxacin. The microorganisms were most resistant to Cefotaxime (28.3\%) followed by Imipenam (15.2\%). There were 10 cases detected to have MRSA (Methicillin Resistant Staphylococcus aureus). All the MRSA strains were shown to be susceptible to Vancomycin, Amikacin and Gentamycin.

Table 10: Sensitivity of the microorganisms to antibiotics.

\begin{tabular}{|lllll|}
\hline \multirow{2}{*}{ Drugs } & \multicolumn{2}{l}{ Sensitivity } & \multicolumn{2}{l|}{ Resistance } \\
\hline Amikacin & N & \% & N & \% \\
\hline Cefazolin & 860 & 70.4 & - & \\
\hline Cefepime & 371 & 30.4 & 146 & 11.9 \\
\hline Cefotaxime & 337 & 27.6 & 67 & 5.5 \\
\hline Ciprofloxacin & 422 & 34.5 & 346 & 28.3 \\
\hline Gentamycin & 577 & 47.2 & 99 & 8.1 \\
\hline Imipenam & 803 & 65.7 & 125 & 10.2 \\
\hline
\end{tabular}

\section{DISCUSSION}

Vaginal infections have various implications for women's health, being the most common gynaecological problem $^{15}$. Prevalence studies indicate that there is a potentially large reservoir of bacterial vaginosis infection in the population. ${ }^{8}$ Microbes play a critical role in determining the biochemical and inflammatory profile of the vaginal environment. ${ }^{16}$ An understanding of the composition of the vaginal microbial ecosystem is essential for comprehensive understanding of the etiology of vaginal infection and for the prevention and treatment of the disease.${ }^{17}$ Our study demonstrates the prevalence of various pathogenic microorganisms in the vagina in symptomatic women. Our study found infection more common in the age group 26-35 years with declining infection with declining age and being least common in the age group 18-25years. A similar high frequency of infection in the age group 20-30 years with a fall in frequency of infection as age advanced was found in a study by Nagalaksmi Narayana Swami et al. ${ }^{18}$ There is a strong association of the presence of bacterial vaginosis with age more than 25 years which is unusual for most sexually transmitted infection in females where the highest rates are always in women younger than 25 years of age. Morris et al states that women aged under 25 years report higher number of sexual partners and higher rate of partner change but report fewer cases of bacterial vaginosis opposing the proposed routes of sexual transmission. ${ }^{8}$ In our study the prevalence of $E$. coli was the highest at $18.2 \%$ followed by Klebsiella pneumonia (9\%), Klebsiella oxytoca $(7.3 \%)$ and staphylococcus $(6 \%)$. The results of our study was comparable to the study by K. Lakshmi, et al who found that Escherichia coli, Staphylococcus aureus and Klebsiella pneumonia were the most common pathogenic bacteria isolated..$^{10} \mathrm{An}$ earlier study by Rahman, et al found Escherichia coli to be the most common pathogenic bacteria $(15 \%)$ isolated from culture. ${ }^{19}$ Burton and Reid reported presence of $E$. coli in $21 \%$ Nagalaksmi, et al found prevalence of $E$. coli of $11.5 \%$ and a prevalence of $17 \%$ was found by Gopal Kumar, et al. ${ }^{18,20,21}$ Our study found staphylococci in $6 \%$ of symptomatic women while Lakshmi, et al found staphylococci aureus in $9.3 \%$ unlike Gopal Kumar, et al who found Staphylococcus aureus in only $1 \% .^{10,21}$ In our study we found Candida species to be isolated in 28 women $(1.4 \%)$ and was more common in age group 2635 years. Lakshmi, et al found Candida species in $16 \%$ of 
women and more common in premenopausal women. ${ }^{10}$ Gopal Kumar, et al found Candida species in $2 \%$ of patients. ${ }^{21}$ It is known that vaginal infections due to a disruption of normal vaginal flora increase the risk of sexually transmitted infections especially HIV. ${ }^{22}$ A recent study in Chicago collecting cervicovaginal lavage specimens found gram stains indicative of Bacterial vaginosis to be significantly associated with a newly identified HIV-Inducing factor that induces HIV-1 Gene expression. ${ }^{23}$ Newer antibiotics like Imipenam are effective but very expensive. ${ }^{24}$ Amikacin and Gentamycin still continue to be drugs to which most of the organisms are sensitive. Lakshmi, et al found most of their gram negative isolates to be highly sensitive to Amikacin, gentamycin and Ceftazidine. They also found that MRSA strains were all found to be susceptible to Vancomycin. ${ }^{10}$ In our study too we found that all the MRSA strains were sensitive to Vancomycin in addition to Amikacin and Gentamycin. High resistance rates have occurred to commonly used antibiotics due to improper and wide indiscriminate use. This study was done to determine the sensitivity and resistance patterns to the commonly used antibiotics thus enabling us to decide on the correct antibiotics to be used.

\section{CONCLUSION}

One of the most common complaints by women attending Gynecology OPD is vaginal infection and it still remains one of the least understood. Our present study provides information about the different microorganisms present in the symptomatic women complaining of vaginal discharge. Pathogenic bacteria like E. coli, Klebsiella, and Staphylococci etc. were more common than Candida species. Hence the principle of empirically treating women with leucorrhoea with an antifungal agent without taking an HVS has to be changed and appropriate treatment is to be given after properly diagnosing the vaginal infection. Appropriate antibacterial agents based on the culture sensitivity results have to be given along with the antifungal agents.

\section{Funding: No funding sources \\ Conflict of interest: None declared \\ Ethical approval: Not required}

\section{REFERENCES}

1. Larsen B, Monif GR. Understanding the bacterial flora of the human genital tract. Clin Infect Dis. 2001;32(4):69-77.

2. Puri R, Malhotra J. Recurrent urinary tract infection (UTI) in women .South Asian Federation of Obstetrics and Gynecology. 2009;1(1):10-3.

3. Allsworth JE, Peipert JF. Prevalence of bacterial vaginosis: 2001-2004 National Health and Nutrition Examination Survey Data. Obstet Gynecol. 2007;109:114-20.

4. Wang J. Bacterial Vaginosis. Prim Care Update $\mathrm{Ob}$ Gyn. 2000;7:181-5.
5. Hillier SL, Nugent RP, Achenbach DA, Krohn MA, Gibbs RS, Martin DH et al. Association between bacterial vaginosis and preterm delivery of a low birth-weight infant. The Vaginal Infections and Prematurity Study Group. N Engl J Med. 1995;333:1737-42.

6. Sweet RL. Role of bacterial vaginosis in pelvic inflammatory disease. Clin Infect Dis. 1995;20(2):S271-5.

7. Haggerty $\mathrm{Cl}$, Hillier SL, Bass DC, Ness RB. Bacterial vaginosis and anaerobic bacteria are associated with endometritis. Clin Infect Dis. 2004;39:990-5.

8. Morris M, Nicole A, Simms I, Wilson J, Catchpole M. Bacterial vaginosis: a public health review. BJOG. 2001;108:439-50.

9. Ravel J, Gajer P, Abdo Z, Schneider GM, Koenig SS, McCulle SL, et al. Vaginal microbiome of reproductive age women. Proct Natl Acad Sci USA. 2011;108(1):4680-7.

10. Lakshmi K, Chitralekha S, Illimani V, Menezes GA. Prevalence of Bacterial vaginal Infections in pre and postmenopausal women Int $\mathrm{J}$ Pharm Bio Sci. 2012;3(4):949-56.

11. Klebanoff MA, Schwebke JR, Zhang J, Nansel Tr, $\mathrm{Yu}$ KF, Andrews WW. Vulvovaginal symptoms in women with bacterial vaginosis. Obstet Gynecol. 2004; 104:267-72.

12. Zhou X, Brown CJ, Abdo Z, Davis CC, Hansmann MA, Joyce $\mathrm{P}$ et al. Differences in the composition of vaginal microbial communities found in healthy Caucasian and Black women. ISME J. 2007;1:12133.

13. Bradshaw CS, Morton AN, Hodcking J, Garland SM, Morris MB, Moss Lm et al. High recurrence rates of bacterial vaginosis over the course of 12 months after oral metronidazole therapy and factors associated with recurrence. J Infect Dis. 2006;193:1478-86.

14. National Committee for Clinical Laboratory Standards. Abbreviated Identification of Bacteria and Yeast Approved Guidelines. NCCLS document M35-A.Wayne PA: NCCLS; 2002.

15. Khan SA, Amir F, Altaf S, Tanveer R. Evaluation of common organisms causing vaginal discharge. J Ayub Med College Abbottabad. 2009;21(2):90-3.

16. Srinivasan S, Fredricks DN. The Human Vaginal Bacterial Biota and Bacterial vaginosis. Interdisciplinary Perspectives on Infectious Diseases. 2008;750479:22.

17. Ling Z, Kong J, Liu F, Zhu H, Chen X, Wang Y, et al. Molecular analysis of the diversity of Vaginal Microbiota associated with bacterial vaginosis. BMC Genomics. 2010;11:488.

18. Narayana-Swami N, Ramalingappa P, Bhatara U. Antimicrobial Sensitivity pattern of Microorganisms isolated from vaginal infections at a Tertiary Hospital in Bangalore, India. IJMS. 2015;3:34-9.

19. Rahman T, Khan IH, Begum J. High vaginal swab (HVS), routine microscopy and culture sensitivity in Diabetic and non diabetic, a comparative 
retrospective study of five years. Indian J Med Sci. 1991;45:212-4.

20. Burton JP, Reid G. Evaluation of the bacterial vaginal flora of 20 post menopausal women by direct (Nugent score) and molecular (Polymerase chain reaction and denaturing gradient gel electrophoresis) techniques. J Infect Dis. 2002;186(12):1770-80.

21. Kumar G, Singh K. Microbial Profile of High vaginal Swab From Symptomatic Women of Reproductive Age Group.Data from Tertiary Care Hospital .Int J Of Science and Research. 2015;4(7):2672-73.

22. Balkus JE, Richardson BA, Mandaliya K, Kiarie J, Jaoko W, Ndinya-Achola JO et al. Establishing and sustaining a healthy vaginal environment: Analysis of data from a randomized trial of periodic presumptive treatment for vaginal infections. J Infect Dis. 2011;204(2):323-6.

23. Olinger GG, Hasemi FB, Sha BE, Spear GT. Association of indicator of bacterial vaginosis with a female genital tract factor that induces expression of HIV-1.AIDS. 1999;13:1905-12.

24. Patel J, Bhatt J, Javiya V, Patel K. Anti-microbial susceptibility patterns of Enterobateriaceae isolated from a tertiary care unit in Gujarat. Internet Journal of Microbiology. 2008:6(1).

Cite this article as: Gopalan U, Sathiyakala R, Karthika J, Karnaboopathy R. Composition of vaginal microbiota and their antibiotic susceptibility in symptomatic women. Int J Reprod Contracept Obstet Gynecol 2017;6:427-32. 